\title{
An elusive case of systemic mastocytosis
}

\author{
JK Lee ${ }^{1 *}$, P Vadas $^{2}$ \\ From Canadian Society of Allergy and Clinical Immunology Annual Scientific Meeting 2009 \\ Halifax, Canada. 22-25 October 2009
}

A 40 year old woman with recurrent "idiopathic" anaphylaxis was referred. Past history revealed a right ovarian mucinous cyst adenoma that was surgically removed. Medications included celebrex and alesse.

Six months following the oopherectomy at age 15, she began to experience anaphylaxis every 2 months. Typically these occurred in late afternoon, not on an empty stomach, and half related to physical activity. During three reactions she self administered epinephrine that led to improvement within minutes. She had one biphasic reaction. She did recall being stung by a vespid but was asymptomatic.

Her two - three hour reactions consisted of abdominal pain, nausea, vomiting, diarrhea, weakness, pruritis with flushing, and documented hypotension. Occasionally, there was nasal congestion, stridor, palpatations, presyncope. On two occasions she had syncope. There were no triggers including cholinergic, foods, and catamenial.

Physical examination was unremarkable. She neither had Darier's sign nor urticaria pigmentosa.

Skin prick testing to common allergens was negative. Her serum tryptase was $8.3 \mathrm{ug} / \mathrm{L}$. Tryptase immediately after a reaction was $33 \mathrm{ug} / \mathrm{L}$. Normetanephrines, metanephrines, vanillymandelic acid, 5-hydroxyindoleacetic acid, 24 hour urine catecholamines for noradrenaline and dopamine, serum chromogranin A and calcitonin were all normal. Her CT abdomen and pelvis was normal.

She continued to have episodes on ranitidine $150 \mathrm{mg}$ and ketotifen $4 \mathrm{mg}$ twice daily as well as cetirizine $20 \mathrm{mg}$ and singulair 10mg once daily.

On bone marrow biopsy she met three WHO minor criteria for systemic mastocytosis: greater than $25 \%$ mast cells having cytologically atypical hypogranular spindle shapes; flow cytometry showing positive aberrant coexpression of CD25 and CD2 on mast cells; and mutational analysis of the c-kit gene being positive for the

${ }^{1}$ Clinical Immunology and Allergy, University of Toronto, Canada
D816V C-KIT mutation. Tryptase at bone marrow aspiration was $7.6 \mathrm{ug} / \mathrm{L}$.

In patients with idiopathic anaphylaxis, consider a bone marrow biopsy for systemic mastocytosis in spite of a negative physical exam and normal tryptase.

\section{Author details}

${ }^{1}$ Clinical Immunology and Allergy, University of Toronto, Canada. ${ }^{2}$ Division of Clinical Immunology and Allergy, St Michael's Hospital, University of Toronto, Canada.

Published: 12 May 2010

doi:10.1186/1710-1492-6-S1-P24

Cite this article as: Lee and Vadas: An elusive case of systemic mastocytosis. Allergy, Asthma \& Clinical Immunology 2010 6(Suppl 1):P24.
Submit your next manuscript to BioMed Central and take full advantage of:

- Convenient online submission

- Thorough peer review

- No space constraints or color figure charges

- Immediate publication on acceptance

- Inclusion in PubMed, CAS, Scopus and Google Scholar

- Research which is freely available for redistribution

Submit your manuscript at www.biomedcentral.com/submit
C Biomed Central 